\title{
Integration of EFQM and Ultimate Six Sigma: A Proposed Model
}

\author{
Arash Shahin (Corresponding author) \\ Department of Management, University of Isfahan, Isfahan, Iran \\ 1.242 Saeb Avenue, 81848-13713, Isfahan, Iran \\ Tel: 98-311-793-2040Ｅ-mail: arashshahin@hotmail.com \\ Reza Pourbahman \\ Department of Industrial Engineering, Islamic Azad University, Najafabad Branch, Isfahan, Iran \\ 13, Motahar Street, Valiasr 24 Meter Avenue, Seyedoshohada Boulevard, 69318-33644, Ilam, Iran \\ Tel: 98-841-333-6526 E-mail: rezapourbahman@ymail.com
}

\begin{abstract}
The aim of this article is to propose a comprehensive integrated model of the EFQM, i.e. European Quality Award, and USS i.e. the Ultimate Six Sigma in order to take more advantage from both of the models simultaneously towards improving organizational performance and excellence. For this purpose, the literature has been reviewed and the structure and criteria of the models have been compared. An integrated model has been developed, in which the USS has been modified and restructured compatible with the EFQM model. The results imply that the proposed integrated model includes simultaneously the criteria of both EFQM and USS models and can be used as an appropriate reference model for assessing organizations in their movement towards excellence. The proposed model includes nine major criteria similar to the EFQM model and 56 sub-criteria similar to the USS model. The criteria have been classified into two categories of enablers and results. Out of 1000 scores of the new model, 795 and 205 scores have been allocated to the enablers and results, respectively, which is different from the EFQM model in which the sum of scores of enablers and results are equally divided (i.e. 500).
\end{abstract}

Keywords: European Quality Award, Ultimate Six Sigma, Excellence, Integration

\section{Introduction}

Determining the status of different systems, methods, and instructions in the structure of organizations; the mode of their relationships with each other; discovering weaknesses and strengths; and improving organizational performance are the managers' subjects of considerable interest. Assessing organizational performance consists of measures and criteria which are used to compare organizations' status with desired level of performance in potentialities and resources in order to achieve excellence, efficiently and effectively. In recent years performance assessment approaches have been improved and among them, the comprehensive models play more important role. Each of the models considering their characteristics, criteria, values, and specific fundamental concepts, among which we can refer to Deming Award Model in Japan, Malcom Baldrige Model in America and the European Foundation for Quality Management (EFQM) award, and most recently, Ultimate Six Sigma (USS) are relatively different and have been prepared for different applications.

Among the popular models, EFQM as a standard reference has been widely utilized having more than 800 members from 38 countries in private and governmental sectors, and is an excellence model in many countries particularly in the European community. It is regarded as a basis for organizational assessment towards excellence. Healthcare centers in countries such as Netherland (Nabitz and Klazinga, 1999), Germany (Moeller, 2001), United Kingdom (Stahr et al., 2000; Jackson, 2001) and Spain (Aeerlay et al., 1999; Ruiz et al., 1999) were the first organizations that have assessed their performance according to the EFQM model. Figure 1 illustrates the number of European countries from 2000 to 2004 that have applying most of the requirements and criteria of the EFQM model with success.

However, it is important to note that no investigation exists on the integration of the EFQM model and other excellence models. The focus of the available resources are on the following two areas:

1) Development of national quality models and awards in various countries based on the structure of EFQM model and with the consideration of native attitudes.

2) Application and implementation of various managerial approaches and systems such as Information Management, Balanced Score Card (BSC), etc. in order to improve the performance of the EFQM model.

Literature addresses an integration of BSC and EFQM models, with a step by step and simultaneous application (Figure 2). The methodology is developed in eight steps as follows: 
1) Self-assessment of the organization based on EFQM model

2) Determining organizational vision and missions

3) Defining organizational strategies by SWOT analysis, and considering internal weaknesses and strengths and external threats and opportunities

4) Fitting the strategies into four perspectives of the Balanced Score Card model

5) Determining the relationship between the defined strategies in Balanced Score Card and EFQM models by the use of House of Quality

6) Ranking strategies

7) Prioritizing strategies by the Balanced Score Card Model

8) Determining organizational performance improvement by re-self-assessment based on the EFQM model

There seems no resources exist addressing the application of USS in organizations as a performance assessment approach and/or integrating it with other excellence models, while the focus of most of the available investigations is on the necessity of using fundamental concepts of traditional Six Sigma along with applying other and performance assessment approaches.

Six Sigma is an effective means towards operational excellence, which in turn is necessary for achieving performance improvement, financial effectiveness, customer orientation and organizational excellence (Edgeman, 2000). Six Sigma specifically interconnects tactical and strategic activities. Therefore, it is compatible with organizational excellence models and National Quality Awards (Klefsjo et al., 2001). It is important to note that the National Quality Awards and Six Sigma projects are both based on similar principals. The apparent similarities include approaches, customer orientation, partnerships, managing data and information, and strategic plans and programs. Thus, the criteria of excellence models and quality awards can be used for selection and prioritization of Six Sigma projects (Przekop, 2006).

From 1987 to 1997, Six Sigma has been widely utilized by Motorola and has led to great advantages including five times increase in production rate, increase of 20 percent of average annual profit, saving 14 billion dollars in the past decade, and also annual increase of 21.3 percent in assets and inventories. Motorola has been recognized as the first winner of the American National Quality Award, i.e. Malcom Baldrige Award (Eckes, 2006).

The aim of this article is to study the criteria, similarities and differences of the EFQM and USS models and to propose an integrated model in order to make it possible for organizations to take the advantage of the two models, simultaneously. For this purpose, EFQM and USS are demonstrated and by comparative analysis of the structures, concepts and criteria of the two models, an integrative model is developed.

\section{European Quality Award (EFQM Model)}

European Foundation for Quality Management (EFQM) is a non-profit organization that has been established in 1988 by fourteen well known European companies (Bosch, Renault, Fiat, BT, Boll, Electrolux, KLM, Nestle, Olivetti, Philips, Solzer, Volkswagen, Razalet, Siba). The mission of this organization is to promote performance excellence, and to create organizational competitiveness in Europe as well as in European organizations throughout the world. In 1999 a model named as National Award of the European Quality was introduced to assess and improve performance of the organizations and was rapidly recognized and adopted by the European companies. The model attracted public service organizations and small industries. In this respect, in 1995 its general section was revised, and in 1996 the model related to small businesses was developed. Although this model was contentiously considered and reviewed by the EFQM, the most important review which results in some changes in the model happened in 1999. The most important changes included more attention to the approaches that affect customers and the partnership and data management. In 2001, the small business model was more coordinated with National Award of the European Quality model and was introduced as the EFQM model. In 2003 and 2010 considerable changes were made into sub-criteria and guidelines. The EFQM, was founded based on a series of fundamental concepts and values which are essential for total organizational performance (regardless of organizational size and functions), that are retrieved from principles of the Total Quality Management. These concepts include result orientation, customer orientation, leadership, stability of aims, reality and process based management, staff participation and development and continuous learning, innovation and improvement, development of partnership and social responsibilities (Ghobadian and Woo, 1996; Eskildsen, 1998; Vander Wiele et al., 2000; Westlund, 2001). In fact, fundamental values and concepts are regarded as the foundation of the model and show the aims to which an organization should access. However, since such aims and desires are ambitious and hard to reach, determination of the criteria becomes critically important. The EFQM model encompasses nine major criteria in two categories. The first five criteria are 
regarded as 'enablers' (including leadership; staff; strategy; partnerships and resources; and processes, products and services) and four of them are referred to as 'results' (including results of the staff; results of customers; results of community; and key results). The model has totally 32 sub-criteria (EFQM, 2010). Enablers' criteria include whatever an organization does, and result criteria include what an organization obtains. In fact, the results are obtained by performing enablers and enablers are improved by feedback from the results. Many performed practical activities and investigations strengthen the hypothesis that there is a close relationship between enablers of EFQM and the criteria and components of the philosophy of Total Quality Management (Dijkstra, 1997; Eskildsen, 1998; Eskildsen and Dahigaard, 2000; Prabhu et al., 2000; Reiner, 2002; Bou-Liusar et al., 2005). The total scores of each of the two parts of the model, i.e. enablers and results is equally 50 percent, as a result the total score of the model is equal to 1000 (i.e. 500 scores for enablers and 500 scores for results). In other words, if an organization successfully and fully applies the model, it can gain 1000 scores.

\section{Ultimate Six Sigma Model}

Continuous improvement plays a major role in accessing business excellence and is the most important competitive advantage for survival of the organizations in highly competitive world of today (Deming, 1986). Thus, most of organizations have concentrated widely on solving existing problems, difficulties and weaknesses in their systems and processes to increase productivity, and finally to achieve competitive advantage to remain stable in the global markets. Organizations are facing variety of problems and obstacles which necessitate managers to use various effective approaches. One of the most effective approaches for eliminating waste and defective products/services is Six Sigma. Six Sigma methodology is one of the advanced quality improvement approaches that has attracted managers and experts of organizations, worldwide (Hutchins, 2000). This Methodology was initially proposed by Bill Smith in 1979, a reliable quality control engineer of Motorola, and then was developed in 90's in General Motors and improved rapidly in various fields. The application of Six Sigma in industries such as Samsung (Chua and Yun, 2002) and General Motors (Conlin, 1998) indicates that it has succeeded practically and assists organizations to move faster towards their desired objectives. Six Sigma is a philosophy based on customers' needs which aims to improve performance of organizations in various dimensions, and to decrease of defective products/services, by which only 3.4 parts per million defects are produced. In other words, Six Sigma is a systematic approach that involves recognition, description, measurement, analysis, improving and standardization of a process. It is important to note that the major cause of raising Six Sigma quality has been the need for improving quality in three major products (Arnheiter and Maleyeff, 2005) as:

1) Complicated products with many parts (e.g. automobile, electronic industries, etc.);

2) High sensitive products (products related to human health, e.g. medical instruments); and

3) Mass products (provided that if they are defectively produced, high losses would be encountered).

Many of the concepts and techniques of Six Sigma are taken from Total Quality Management. They include:

- Changing the organizational structure and culture

- Identifying improvement and/or redesigning organizational processes

- Concentrating on customers and involving their desires, expectations and requirements in designing the process and quality of the product

- $\quad$ Analyzing statistical data by using control charts and diagrams (Statistical Quality Control)

- $\quad$ Training and motivating staff of the organization, partnership and team working

Six Sigma Methodology has a coherent and regular approach that can be summarized to three inclusive concepts ( $\mathrm{Su}$ et al., 2005) as:

1) Continuous improvement in a series of sequential steps, which is recognized as the cycle of Define-Measure-Analyze-Improve-Control (DMAIC) as illustrated in Figure 3. In the following, the components of the DMAIC cycle are further demonstrated:

- Define: In this step, improvement project is defined according to the aims of the organization and customers' priorities and needs

- Measure: The aim of this step is to measure the process performance, and to collect data for problem solving

- Analysis: This step includes analyzing collected data and process map to identify cause of errors and recognizing opportunities for improvement

Improve: The aim of this step is to decrease, and if possible eliminate errors and deficiencies in order to increase quality and improving process performance 
- Control: The aim of this step is to maintain improvements made in the previous steps by continuous control of the process performance

2) Combining human resources and processes, by using Belts symbol. Different belts denote people who implement Six Sigma who are divided into five groups as Champions, Master Black Belts, Black Belts, Green Belts, and White Belts.

3) Monitoring the obtained results and maintaining and empowering them continuously and permanently.

The model of Ultimate Six sigma (USS) was first developed in 2003 to assess organizational performance and the rate of organizational success in accessing Six Sigma Quality. Since then, the Six Sigma approach has been upgraded from "Excellence of Quality" to "Business Excellence", i.e. excellence in the whole organization (Bhote, 2003). This model is formed in four areas and includes 12 major criteria as:

- Area of stakeholders including five criteria of customers, leadership, organization, staff, and the chain of suppliers

- Area of basic skills and techniques including three criteria of quality, cost, and cycle time

- Area of functional areas including three criteria of design, production and services

- $\quad$ Area of results including one criterion of results

In addition, the model includes totally 61 sub-criteria. Each of customers and leadership criteria has 100 scores, regarding to their importance and position, and each of the other 10 criteria has 80 scores, and the total score of the model is equal to 1000 , similar to the EFQM model. The amount of organizational success in achieving the Six Sigma Quality is assessed with respect to the total scores obtained and is categorized into one of the Sigma levels addressed in Table 1.

\section{New methodology}

Considering the structure, concepts, and criteria of the EFQM model and USS and their comparison, the following comments are made:

- The basic values and concepts of the USS that are apparent in its criteria and sub-criteria are comprehensive and contains almost all of the assumed concepts, values, and criteria of the EFQM model and even beyond it. In many cases the USS includes strategies and means of accessing to the criteria. It consists of quantitative goals with specific details, while in the EFQM model, lack of such characteristics is apparent and its guidelines are not clearly explained and do not identify the needs of managers and users in case of performance levels. Compared to USS, it should be clarified that EFQM provides only a general framework for the users and assists them in achieving their performance goals.

- Regarding the information feedback cycle, it is important to note that in EFQM, the information feedback (for the purpose of learning and growth) is utilized after results assessment, and it is not possible to define a particular reward system in the model, respectively, while in the USS model by the use of effective information feedback systems (including internal customers and suppliers subjects), identifying the weaknesses and strengths and gaining the required result by correction actions, and even considering suitable rewarding systems are facilitated.

- Since the EFQM model as a business excellence model has been adopted and employed globally more than the other models and has systematic approach, framework, and structure that clearly illustrate the relationship between criteria, it is decided to restructure the criteria and scores of the USS according to the EFQM framework.

In a comparison of the two models, it is found that the four criteria of USS and the nine criteria of EFQM are surprisingly compatible with a minor difference and therefore, there is no need to add extra items into the EFQM model. In other words, three out of four criteria of the USS model, i.e. stakeholders, basic skills and techniques and functional areas are mostly in consistent with the enablers of EFQM; in addition, the sub-criterion of the results of USS model, could be divided into the results of the EFQM model, i.e. customers' results, staff's results, community's results, and key business results.

As an example, the determination of the sub-criteria and scores of the criterion of 'processes, products and services' of the integrative model, that among the criteria has assigned as the highest score is described as follows:

In the first step, after comparing the criteria of USS model with the criterion of 'processes, products, and services' of EFQM, it is discovered that some of the criteria and sub-criteria of the USS model, which are compatible with the sub-criteria of EFQM include:

- $\quad$ sub-criteria 6.6, 6.7 and 6.8 are related to quality sub-criterion 
- $\quad$ sub-criteria 7.5 and 7.6 are related to cost reduction sub-criterion

- $\quad$ sub-criteria 8.2, 8.3 and 8.6 are related to cycle time reduction sub-criterion

- criteria of functional areas, i.e. designing, production and services

It is concluded that there are consistency between some of the above mentioned criteria and sub-criteria. As an example, sub-criteria 6.6 from quality criterion, and sub-criteria 9.4 from designing criterion, and/or consistency of sub-criteria 8.3 from cycle time reduction criterion, and sub-criteria 10.3 from production criterion are all classified into the criterion of 'processes, products and services' criterion in the proposed integrated model.

Continuing the discussion, the structure of the proposed model is illustrated in Figure 4 and the scores of each criterion and their sub-criteria of enablers and results which are restructures into the proposed model are presented in Table 2.

\section{Discussion and conclusions}

In this article, the EFQM and USS models were introduced and by comparing their structure, concepts, and criteria, an integrated model was proposed in order to make it possible for managers and decision makers to take more advantages out of both approaches, simultaneously. The proposed integrated model includes nine major criteria (similar to the EFQM model). The 56 sub-criteria of the USS model are allocated to the enablers and results area. Total scores of the proposed model is 1000, out of which, the enablers criteria consist of 795 scores and the results criteria consist of 205 scores. Among the model criteria, the 'processes, products, and services' criterion has the highest scores. This is reasonable, since the main aim of the USS model which is derived from Six Sigma methodology is to reach defect free product/service from the beginning steps of identifying vision, mission, and organizational goals. Hence its result oriented strategies are focused on product/service and process design until production. The main emphasis of the USS model is on information feedback (e.g. from customers and suppliers) in order to enhance enablers area ( 795 scores); this is the main reason why the results area of the model ( 205 scores) has less scores compared to the EFQM model (500 scores) and other excellence models.

\subsection{Research contribution and managerial implications}

The proposed model of this article develops EFQM and USS models and provides many advantages compared to each of the individual models. The integrated model is suitable for assessing organizations in their ways towards competitiveness and excellence.

The structure and framework of the proposed model is compatible with the systematic structure of the EFQM model, which their criteria and the relationships among them are defined properly by dividing them into two areas of enablers and results. On the other hand, necessary approaches and systems along with quantity aims and indicators and also the way of scoring which are addressed in the framework of sub-criteria are derived from the USS model, which in turn has a more complete methodology than traditional Six Sigma (DMAIC cycle).

While the EFQM model like other national and international quality awards has a scoring system and classifies organizations according to their obtained scores, gives them rewards (certification, awards, etc.), and assists organizations in leading competition, in the USS model such scoring is performed to assist organizations in determining the Sigma level. In the USS model, the output is more emphasized and it is not used similar to the EFQM model for competition. The proposed model resolves such problem by the integration of the two models and separating the criteria of USS model into two areas of enablers and results.

In the EFQM model, information feedback is considered from results to enablers, which is a means of learning and growth and leads to improvement of enablers. In the USS model, separation of factors into enablers and results is not considered and information feedback is realized as a criterion and therefore, a general assessment of the organization cannot be deployed similar to the EFQM model. Hence, the integration of the two models resolves such weakness of the USS model.

The European Quality Award, like other national and international quality awards is developed for organizational excellence and general assessment of the organizations, while the USS model seems mostly useful for improvement of products and services. Therefore, integration of the two models delivers a model that has an award-like approach, and could be employed for achieving organizational excellence in addition to improvement in projects, products, and services.

The main aim of the traditional Six Sigma is profitability, but it is not clear how much its methodology is aligned with such aim as the fundamental aspect of organizational performance, while in the proposed model with its award-like approach, such strategic alignment is considered. Moreover, since Six Sigma projects are defined and managed by teams, such teams are expected to have higher effectiveness in the proposed model. 


\subsection{Research limitations and future research}

In the EFQM model and other quality awards, organizational self-assessment is usually performed by questionnaire, and due to the length of questionnaires, data collection is time-taking and costly. In this respect, new ways with high efficiency for performing self-assessment are always preferred. Since the structure of the proposed model is compatible with the structure of the EFQM model, new ways with less time and cost than the questionnaire approach should be developed to perform self-assessment.

In the Six Sigma approach, the emphasis is on outputs and therefore, the level of Six Sigma is based on real data; but since the proposed model is developed compatible with the structure of EFQM and self-assessment, the data is collected by questionnaire and it is qualitative and conceptual.

As it was addressed, in the proposed model, the scores are mostly allocated to the enablers' area and relatively few scores are assigned to the results area; while in the traditional Six Sigma, output and profitability are more emphasized. In this respect, the proposed model which is partly based on the USS model, may not be necessarily efficient and considering the fact that one of the Deming's fourteen principles, is to avoid stability in the quantitative standards and goals, the proposed model should be revised and adjusted (similar to ISO 9000, EFQM, etc. which have been revised since 20 years ago) as a subject of future research. Furthermore, in EFQM the relative importance between the criteria is not considered and the total score of 1000 is equality allocated to enablers and results (500 scores for each), while in the integrated model, the results have less scores (205) compared to enablers (795). This is an inconsistency to the Six Sigma philosophy in which the outputs (results) are more important. However, to solve such a contradiction, the Multiple Criteria Decision Making approaches could be utilized to determine relative weight of importance for each of the criteria, which in turn will adjust the unbalanced scores of the two areas of the proposed model.

While the integration of EFQM and USS was satisfactorily performed due to the high similarities between the two models, in some cases some differences existed and made the integration relatively difficult. However, in order to increase the accuracy of the scoring approach, further research is needed.

Although the proposed model was theoretically demonstrated and discussed, it lacks empirical investigation; therefore in order to perform necessary structural modifications, the proposed model should be applied in various organizations and industries and the results should be compared and analyzed. Even the new theory needs to be confirmed with more confidence and for this purpose; viewpoints of more experts and specialists should be collected and analyzed.

As it was addressed in Table 1, in the USS approach it is possible to determine the approximate sigma level according to the obtained scores. Therefore, in order to have the same advantage in the proposed approach, further investigations is needed in different organizations in order to study the correlation between sigma level and the scores.

\section{References}

Akbarian, M. \& Najafi, A.A. (2009). Alignment of EFQM and strategic management towards performance improvement. Iranian Journal of Industrial Management, 1(2), 19-34.

Arcelay, A., Sanchez, E., Hernandez, L., Inclan, G., Bacigalupe, M., Letona, J., Gonzalez, R.M. \& Martinez-Conde, A.E. (1999). Self-assessment of all the health centers of a public health service through the European model of Total Quality Management. International Journal of Health Care Quality Assurance, 12(2), 54-58.

Arnheiter, E.D. \& Maleyeff, J. (2005). The integration of lean management and Six Sigma. The TQM Magazine, 17(1), 5-18.

Bhote, K.R. (2003). The Power of Ultimate Six Sigma. First Edition, New York: AMACOM.

Bou-Llusar, J.C., Escrig, A.B., Roca, V. \& Beltran, I. (2005). To what extent do enablers explain results in the EFQM excellence model? An empirical study. International Journal of Quality \& Reliability Management, 22(4), 337-353.

Chua, R.C.H. \& Yun, J.Y. (2002). Samsung uses six sigma to change its image. ASQ Six Sigma Forum Magazine, 2(1), 13-16.

Conlin, M. (1998). Revealed at last: the secret of Jack Welch's success. Forbes, 161(2), 44-45.

Deming, W.E. (1986). Out of the crisis. Second edition, Cambridge, MA: MIT Press.

Dijkstra, L. (1997). An empirical interpretation of the EFQM framework. European Journal of Work \& Organizational Psychology, 6(3), 321-341.

Eckes, G. (2006). Six Sigma execution. New York: McGraw-Hill. 
Edgeman, R.L. (2000). New voices of quality: 21 for the 21st century. in M. Maguire, (Ed.), Quality Progress, 33, 31-39.

EFQM (2010). EFQM Model for Business Excellence. Brussels: European Foundation for Quality Management.

Eskildsen, J.K. (1998). Identifying the vital few using the European Foundation for Quality Management Model. Total Quality Management, 9(4/5), S92-S95.

Eskildsen, J.K. \& Dahlgaard, J.J. (2000). A causal model for employee satisfaction. Total Quality Management, 11(8), 1081-1094.

Ghobadian, A. \& Woo, H.S. (1996). Characteristics, benefits and shortcomings of four major quality awards. International Journal of Quality \& Reliability Management, 13(2), 10-44.

Heras, S., Arana, G. \& Casadesus, M. (2006). A Delphi study on motivation for ISO 9000 and EFQM. International Journal of Quality \& Reliability Management, 23(7), 807-827.

Hutchins, D. (2000). The power of Six Sigma in practice. Measuring Business Excellence, 4(2), 26-33.

Jackson, S. (2001). Using the EFQM Excellence Model in Healthcare: A Practical Guide to Success. Chichester: Kingsham Press.

Klefsjo, B., Wiklund, H. \& Edgeman, R.L. (2001). Six sigma seen as a methodology for Total Quality Management. Measuring Business Excellence, 5(2), 31-35.

Kumar, D. (2006). Six sigma best practices: a guide to business process excellence for diverse industries, New York, NY: J. Ross Publishing.

Moeller, J. (2001). The EFQM excellence model - German experiences with the EFQM approach in health care. International Journal for Quality in Health Care, 13(1), 45-49.

Nabitz, U.W. \& Klazinga, N.S. (1999). EFQM approach and the Dutch Quality Award. International Journal of Health Care Quality Assurance, 12(2), 65-70.

Prabhu, V., Appleby, A., Yarrow, D. \& Mitchell, E. (2000). The impact of ISO9000 and TQM on best practice/performance. The TQM Magazine, 12(2), 84-91.

Przekop, P. (2006). Six Sigma for business excellence. New York: McGraw-Hill.

Reiner, G. (2002). Analysis of critical factors of company success based on the EFQM Excellence model. Proceedings of the 7th World Congress for Total Quality Management, Vol. 2, Verona, Italy, 361-366.

Ruiz, U., Simon, J., Molina, P., Jimenez, J. \& Grandal, J. (1999). A two-level integrated approach to self-assessment in healthcare organizations. International Journal of Health Care Quality Assurance, 12(4), 135-142.

Stahr, H., Bulman, B. \& Stead, M. (2000). The Excellence Model in the Health Sector - Sharing Good Practice. Chichester: Kingsham Press.

Su, C.T., Chiang, T.L. \& Chiao, K. (2005). Optimizing the IC delamination quality via six- sigma approach. IEEE Transactions on Electronics Packaging Manufacturing, 28(3), 241-248.

Van der Wiele, A., Williams, A.R.T. \& Dale, B.G. (2000). ISO 9000 series registration to business excellence: the migratory path. Business Process Management, 6(5), 417-427.

Westlund, A.H. (2001). Measuring environmental impact on society in the EFQM system. Total Quality Management, $12(1), 125-135$.

Table 1. Total rating: a corresponding business health and equivalent sigma level (Bhote, 2003)

\begin{tabular}{ccc}
\hline Total Company Rating & Equivalent Business Health & Equivalent Sigma Level \\
\hline $800-1000$ & Robust health & 6 Sigma \\
$600-799$ & Good health, but periodic physical checkups urged & 5 Sigma \\
$400-599$ & Poor health; continued monitoring Needed & 4 Sigma \\
$200-399$ & Major surgery required & 3 Sigma \\
Below200 & Terminally ill & 2 Sigma \\
\hline
\end{tabular}


Table 2. Criteria, sub-criteria and scores of the integrated model of EFQM and USS

\begin{tabular}{|c|c|c|c|c|c|}
\hline & Enablers & Score & & Results & Score \\
\hline & 1. Leadership & 110 & & 6. Customer Results & 130 \\
\hline 1.1 & Personal philosophies/values & 50 & 6.1 & Customer differentiation & 10 \\
\hline 1.2 & Enabling people to reach their full potential & 50 & 6.2 & Customer loyalty metrics & 30 \\
\hline 1.3 & Quality & 5 & 6.3 & Customer "wow" & 20 \\
\hline \multirow[t]{2}{*}{1.4} & Cost reduction & 5 & 6.4 & Customer cultivation & 25 \\
\hline & 2. Strategy & 125 & 6.5 & Company infrastructure for customer loyalty & 15 \\
\hline 2.1 & Dismantling Taylorism & 5 & 6.6 & Quality & 10 \\
\hline 2.2 & Assault on bureaucracy & 20 & 6.7 & Cost reduction & 5 \\
\hline 2.3 & Revamping the organizational structure & 15 & 6.8 & Results (primary) & 15 \\
\hline 2.4 & Revolutionizing management practices & 30 & & 7. People Results & 20 \\
\hline 2.5 & Egalitarianism & 10 & 7.1 & Results (primary) & 20 \\
\hline 2.6 & Quality & 10 & & 8. Society Results & 5 \\
\hline \multirow[t]{2}{*}{2.7} & Cost reduction & 35 & 8.1 & $\begin{array}{l}\text { Public perceptions of company as employer and } \\
\text { responsible citizen }\end{array}$ & 5 \\
\hline & 3. People & 95 & & 9. Key Results & 50 \\
\hline 3.1 & Motivation & 10 & 9.1 & Quality & 10 \\
\hline 3.2 & Job redesign & 5 & 9.2 & Leadership & 20 \\
\hline 3.3 & Creating an empowering climate & 35 & 9.3 & Financials & 20 \\
\hline 3.4 & Team competition & 5 & & & \\
\hline 3.5 & On the road to empowerment & 25 & & & \\
\hline 3.6 & Quality & 10 & & & \\
\hline \multirow[t]{2}{*}{3.7} & Cycle time reduction & 5 & & & \\
\hline & 4. Partnerships \& Resources & 120 & & & \\
\hline 4.1 & Company policies & 15 & & & \\
\hline 4.2 & Partnership supplier selection & 20 & & & \\
\hline 4.3 & Supply chain infrastructure & 25 & & & \\
\hline 4.4 & Supplier development & 20 & & & \\
\hline 4.5 & Quality & 5 & & & \\
\hline 4.6 & Cost reduction & 20 & & & \\
\hline \multirow[t]{2}{*}{4.7} & Cycle time reduction & 15 & & & \\
\hline & 5. Processes, Products \& Services & 345 & & & \\
\hline 5.1 & Organization for new product development & 5 & & & \\
\hline 5.2 & Management guidelines & 15 & & & \\
\hline 5.3 & "Voice of the Customer" & 10 & & & \\
\hline 5.4 & Design quality/reliability & 30 & & & \\
\hline 5.5 & Design cost reduction & 20 & & & \\
\hline 5.6 & Design cycle time reduction & 25 & & & \\
\hline 5.7 & Creativity and innovation & 110 & & & \\
\hline 5.8 & Manufacturing resurgence & 10 & & & \\
\hline 5.9 & Quality improvement in manufacturing & 45 & & & \\
\hline 5.10 & Cycle time improvement in manufacturing & 45 & & & \\
\hline 5.11 & General & 15 & & & \\
\hline 5.12 & Cost reduction & 10 & & & \\
\hline 5.13 & NOAC principles/practices & 20 & & & \\
\hline 5.14 & NOAC structure & 20 & & & \\
\hline 5.15 & NOAC implementation & 15 & & & \\
\hline 5.16 & NOAC improvements; "Out-of-Box" Thinking & 25 & & & \\
\hline 5.17 & Quality & 10 & & & \\
\hline 5.18 & Support services for cycle time reduction & 15 & & & \\
\hline
\end{tabular}

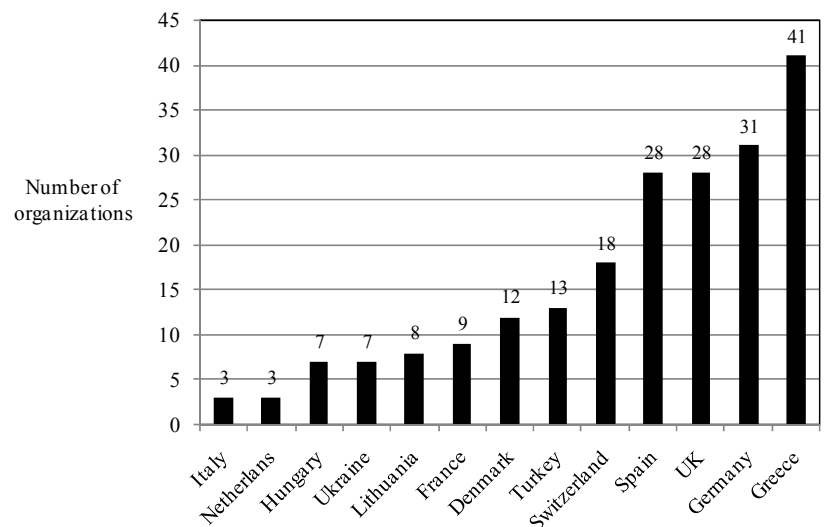

Figure1. Organizations recognized by the EFQM as successful in terms of excellence from 2000 to 2004 (Saizarbitoria et al., 2006) 


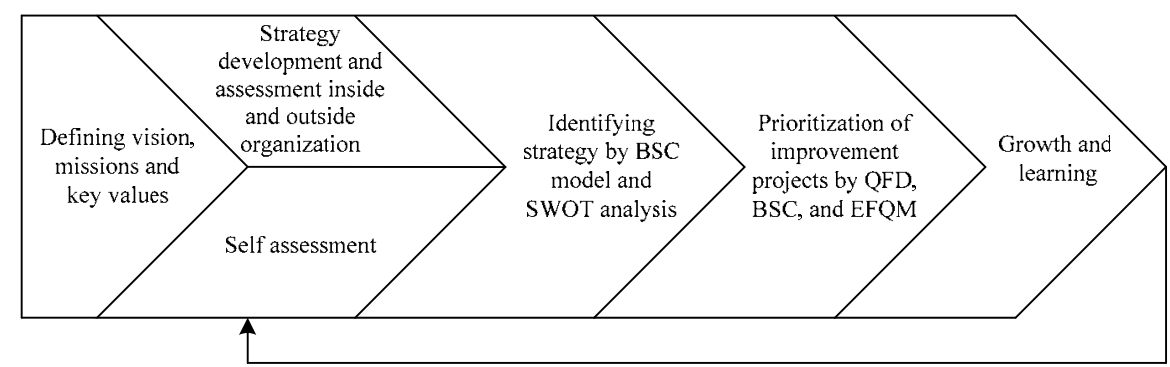

Figure2. Integration of BSC and EFQM (Akbarian, 2009)

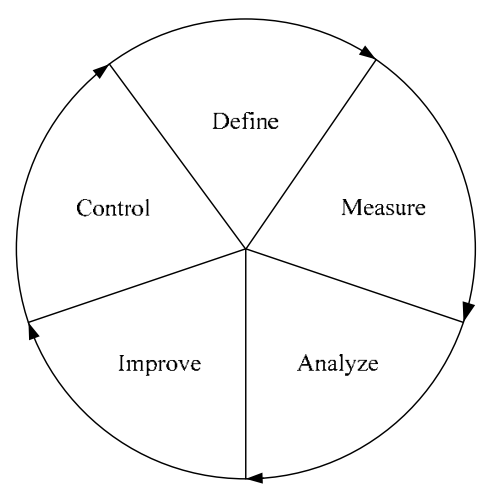

Figure 3. The DMAIC Cycle (Kumar, 2006)

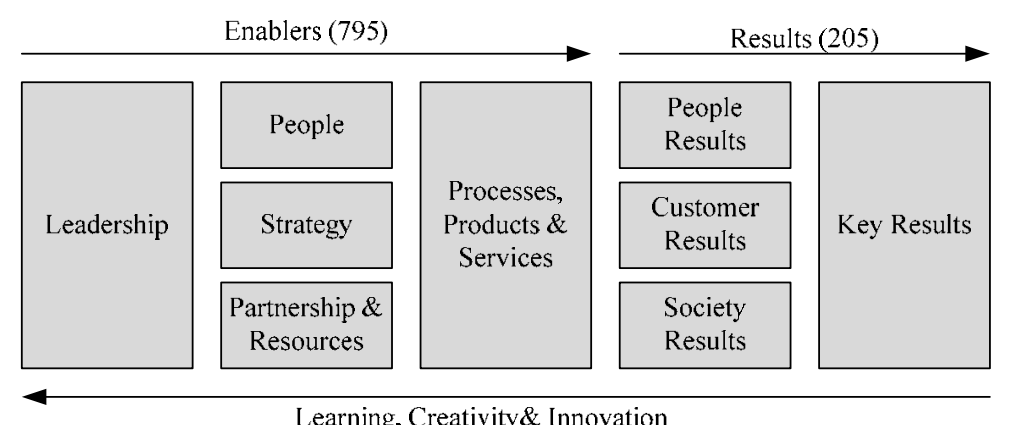

Figure 4. The integrated model of EFQM and USS

Appendix 1. The EFQM model (EFQM, 2010)

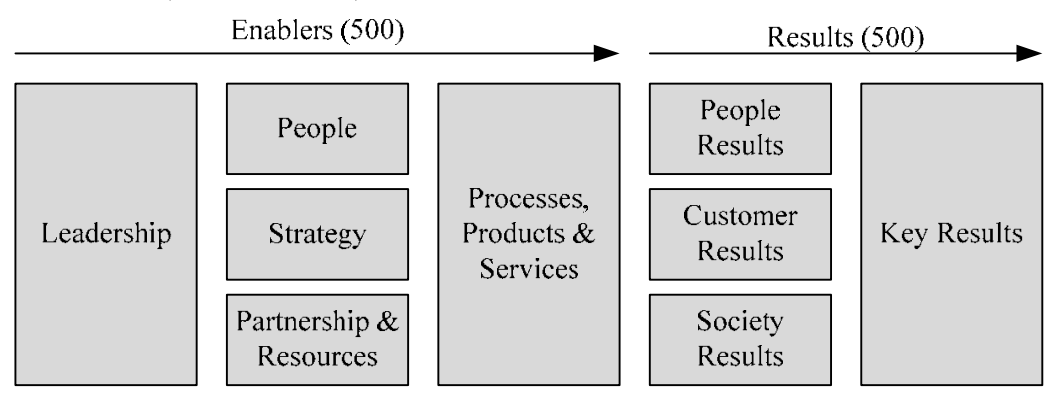

Learning, Creativity\& Innovation 
Appendix 2. Criteria, sub-criteria and scores of the EFQM model (EFQM, 2010)

\begin{tabular}{|c|c|c|c|c|c|}
\hline & Enablers & $\begin{array}{c}\text { Scor } \\
\text { e }\end{array}$ & & Results & Score \\
\hline & 1. Leadership & 100 & & 6. Customer Results & 150 \\
\hline 1.a & $\begin{array}{l}\text { Leaders develop the mission, vision, values and ethics and act as } \\
\text { role models }\end{array}$ & 20 & 6.a & Perception measures & 112.5 \\
\hline 1.b & $\begin{array}{l}\text { Leaders define, monitor, review and drive the improvement of the } \\
\text { organization's management system and performance }\end{array}$ & 20 & 6.b & Performance Indicators & 37.5 \\
\hline 1.c & $\begin{array}{l}\text { Leaders engage with customers, partners and representatives of } \\
\text { society }\end{array}$ & 20 & & 7. People Results & 100 \\
\hline $1 . \mathrm{d}$ & $\begin{array}{l}\text { Leaders reinforce a culture of excellence with the organisation's } \\
\text { people }\end{array}$ & 20 & 7.a & Perception measures & 75 \\
\hline \multirow[t]{2}{*}{ 1.e } & $\begin{array}{l}\text { Leaders ensure that the organisation is flexible and manages change } \\
\text { effectively }\end{array}$ & 20 & 7.b & Performance Indicators & 25 \\
\hline & 2. Strategy & 100 & & 8. Society Results & 100 \\
\hline 2.a & $\begin{array}{l}\text { Strategy is based on understanding the needs and expectations of } \\
\text { both stakeholders and the external environment }\end{array}$ & 25 & $8 . \mathrm{a}$ & Perception measures & 50 \\
\hline 2.b & $\begin{array}{l}\text { Strategy is based on understanding internal performance and } \\
\text { capabilities }\end{array}$ & 25 & 8.b & Performance Indicators & 50 \\
\hline 2.c & $\begin{array}{l}\text { Strategy and supporting policies are developed, reviewed and } \\
\text { updated to ensure economic, societal and ecological sustainability }\end{array}$ & 25 & & 9. Key Results & 150 \\
\hline \multirow[t]{2}{*}{ 2.d } & $\begin{array}{l}\text { Strategy and supporting policies are communicated and deployed } \\
\text { through plans, processes and objectives }\end{array}$ & 25 & 9.a & Key Strategic Outcomes & 75 \\
\hline & 3. People & 100 & $9 . \mathrm{b}$ & Key Performance Indicators & 75 \\
\hline 3.a & People plans support the organisation's strategy & 20 & & & \\
\hline 3.b & People's knowledge and capabilities are developed & 20 & & & \\
\hline 3.c & People are aligned, involved and empowered & 20 & & & \\
\hline $3 . \mathrm{d}$ & People communicate effectively throughout the organisation & 20 & & & \\
\hline 3.e & People are rewarded, recognised and cared for & 20 & & & \\
\hline 3.3 & Creating an empowering climate & 35 & & & \\
\hline 3.4 & Team competition & 5 & & & \\
\hline 3.5 & On the road to empowerment & 25 & & & \\
\hline 3.6 & Quality & 10 & & & \\
\hline \multirow[t]{2}{*}{3.7} & Cycle time reduction & 5 & & & \\
\hline & 4. Partnerships \& Resources & 100 & & & \\
\hline 4.a & Partners and suppliers are managed for sustainable benefit & 20 & & & \\
\hline 4.b & Finances are managed to secure sustained success & 20 & & & \\
\hline 4.c & $\begin{array}{l}\text { Buildings, equipment, materials and natural resources are managed } \\
\text { in a sustainable way }\end{array}$ & 20 & & & \\
\hline 4.d & Technology is managed to support the delivery of strategy & 20 & & & \\
\hline \multirow[t]{2}{*}{ 4.e } & $\begin{array}{l}\text { Information and knowledge are managed to support effective } \\
\text { decision making and to build the organisational capability }\end{array}$ & 20 & & & \\
\hline & 5. Processes, Products \& Services & 100 & & & \\
\hline $5 . \mathrm{a}$ & Processes are designed and managed to optimise stakeholder Value & 20 & & & \\
\hline 5.b & $\begin{array}{l}\text { Products and Services are developed to create optimum value for } \\
\text { customers }\end{array}$ & 20 & & & \\
\hline 5.c & Products and Services are effectively promoted and marketed & 20 & & & \\
\hline $5 . \mathrm{d}$ & Products and Services are produced, delivered and managed & 20 & & & \\
\hline 5.e & Customer relationships are managed and enhanced & 20 & & & \\
\hline
\end{tabular}

Appendix 3. The Ultimate Six Sigma model (Bhote, 2003)

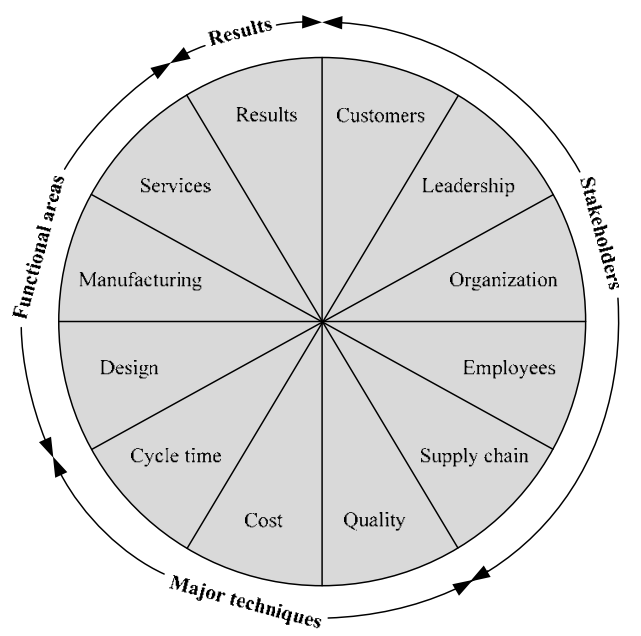


Appendix 4. Criteria, sub-criteria and scores of the Ultimate Six sigma model (Bhote, 2003)

\begin{tabular}{|c|c|c|c|c|c|}
\hline & Stakeholders & Score & & Major techniques & Score \\
\hline & 1. Customers & 100 & & 6. Quality & 80 \\
\hline 1.1 & Customer Differentiation & 10 & 6.1 & Customers & 10 \\
\hline 1.2 & Customer Loyalty Metrics & 30 & 6.2 & Leadership & 5 \\
\hline 1.3 & Customer "Wow" & 20 & 6.3 & Organization & 10 \\
\hline 1.4 & Customer Cultivation & 25 & 6.4 & Employees & 10 \\
\hline \multirow[t]{2}{*}{1.5} & Company Infrastructure for Customer Loyalty & 15 & 6.5 & Supply Chain Management & 5 \\
\hline & 2. Leadership & 100 & 6.6 & Design & 15 \\
\hline 2.2 & Personal Philosophies/Values & 50 & 6.7 & Manufacturing & 5 \\
\hline \multirow[t]{2}{*}{2.2} & Enabling People to Reach Their Full Potential & 50 & 6.8 & Services & 10 \\
\hline & 3. Organization & 80 & 6.9 & Results & 10 \\
\hline 3.1 & Dismantling Taylorism & 5 & & 7. Cost reduction & 80 \\
\hline 3.2 & Assault on Bureaucracy & 20 & 7.1 & Customers & 5 \\
\hline 3.3 & Revamping the Organizational Structure & 15 & 7.2 & Leadership & 5 \\
\hline 3.4 & Revolutionizing Management Practices & 30 & 7.3 & Supply Chain Management & 20 \\
\hline \multirow[t]{2}{*}{3.5} & Egalitarianism & 10 & 7.4 & Tools & 35 \\
\hline & 4. Employees & 80 & 7.5 & Design & 5 \\
\hline 4.1 & Motivation & 10 & 7.6 & Manufacturing & 10 \\
\hline 4.2 & Job Redesign & 5 & & 8. Cycle time reduction & 80 \\
\hline 4.3 & Creating an Empowering Climate & 35 & 8.1 & Supply Chain & 10 \\
\hline 4.4 & Team Competition & 5 & 8.2 & Design & 15 \\
\hline \multirow[t]{2}{*}{4.5} & On the Road to Empowerment & 25 & 8.3 & Manufacturing & 30 \\
\hline & 5. Supply Chain Management & 80 & 8.4 & Employees & 5 \\
\hline 5.1 & Company Policies & 15 & 8.5 & Customer/Supplier & 5 \\
\hline 5.2 & Partnership Supplier Selection & 20 & 8.6 & Support Services & 15 \\
\hline 5.3 & Supply Chain Infrastructure & 25 & & & \\
\hline 5.4 & Supplier Development & 20 & & & \\
\hline
\end{tabular}

\begin{tabular}{|c|c|c|c|c|c|}
\hline & Functional areas & Score & & Results & Score \\
\hline & 9. Design & 80 & & 12. Results (primary) & $\mathbf{8 0}$ \\
\hline 9.1 & Organization for New Product Development & 5 & 12.1 & Customer & 20 \\
\hline 9.2 & Management Guidelines & 15 & 12.2 & Leadership & 20 \\
\hline 9.3 & "Voice of the Customer" & 10 & 12.3 & Employees & 20 \\
\hline 9.4 & Design Quality/Reliability & 15 & 12.4 & Financials & 20 \\
\hline 9.5 & Design Cost Reduction & 15 & & & \\
\hline 9.6 & Design Cycle Time Reduction & 10 & & & \\
\hline 9.7 & Creativity and Innovation & 10 & & & \\
\hline & 10. Manufacturing & 80 & & & \\
\hline 10.1 & Manufacturing Resurgence & 10 & & & \\
\hline 10.2 & Quality Improvement in Manufacturing & 40 & & & \\
\hline 10.3 & Cycle Time Improvement in Manufacturing & 15 & & & \\
\hline 10.4 & General & 15 & & & \\
\hline & 11. Services & 80 & & & \\
\hline 11.1 & NOAC Principles/Practices & 20 & & & \\
\hline 11.2 & NOAC Structure & 20 & & & \\
\hline 11.3 & NOAC Implementation & 15 & & & \\
\hline 11.4 & NOAC Improvements; "Out-of-Box" Thinking & 25 & & & \\
\hline
\end{tabular}

